\title{
Hope and attitudes related to suicidal behavior among nursing students
}

\author{
Esperança e atitudes relacionadas ao comportamento suicida entre graduandos de Enfermagem \\ Esperanza y actitudes relacionadas con la conducta suicida entre estudiantes de enfermería
}

Received: 07/22/2021 | Reviewed: 07/28/2021 | Accept: 07/30/2021 | Published: 08/05/2021

Bruna Marques Chiarelo
ORCID: https://orcid.org/0000-0001-8396-8874
University of São Paulo, Brazil
E-mail: bruna.chiarelo15@gmail.com
Amanda Heloisa Santana da Silva
ORCID: https://orcid.org/0000-0002-2129-9641
University of São Paulo, Brazil
E-mail: amandasantanasilva@ gmail.com
Isabelle Wengler Silva
ORCID: https://orcid.org/0000-0001-9034-0129
University of São Paulo, Brazil
E-mail: isabelle.wengler.silva@ @usp.br
Ana Carolina Guidorizzi Zanetti
ORCID: https://orcid.org/0000-0003-0011-4510
University of São Paulo, Brazil
E-mail: carolzan@eerp.usp.br
Maria Betânia Tinti de Andrade
ORCID: https://orcid.org/0000-0003-0329-1299
Federal University of Alfenas, Brazil
E-mail: betania.andrade@ unifal-mg.edu.br
Kelly Graziani Giacchero Vedana
ORCID: https://orcid.org/0000-0001-7363-2429
University of São Paulo, Brazil
E-mail: kellygiacchero@eerp.usp.br

\begin{abstract}
Objective: to investigate, among nursing undergraduate students, the predictors of hope, suicidal thoughts and attitudes related to suicidal behavior. Methodology: Cross-sectional study, with a quantitative approach, developed in 2018 with 337 undergraduates from a Brazilian public university. We applied a sociodemographic, clinical and psychosocial questionnaire; the Suicide Behavior Attitude Questionnaire and the Herth Hope Scale. We used mean comparison tests, Pearson's correlation test and binary logistic regression. Results: Predictors of hopelessness were psychiatric diagnoses, mental health treatment, absence of religious beliefs and dissatisfaction with the received social support. The chances of suicidal thoughts were higher among people with psychiatric diagnoses, dissatisfaction with the received social support, more understanding of the right to suicide and hopelessness. Predictors of more negative feelings about suicidal behavior were less professional competence and non participation in scientific events. Older students and those with less suicidal thoughts increased the chances of condemnatory attitudes. Predictors of fewer self-perceived competence were negative feelings about suicidal behavior, dissatisfaction with social support and less educational exposure (previous reading of suicide prevention materials or participation in events) and not having friends/relatives at suicide risk. Conclusion: it is important to develop and evaluate undergraduate support and educational strategies that consider the factors investigated in this study, in order to promote hope and training for suicide prevention.
\end{abstract}

Keywords: Hope; Health knowledge, attitudes, practice; Nursing.

\section{Resumo}

Objetivo: investigar, entre graduandos de enfermagem, os preditores para esperança, pensamentos suicidas e atitudes frente ao comportamento suicida. Método: Estudo transversal, de abordagem quantitativa, desenvolvido em 2018 com 337 graduandos de uma Universidade pública brasileira. Foram aplicados o questionário sociodemográfico, clínico e psicossocial; o Questionário de Atitudes frente ao Comportamento Suicida e a Escala de Esperança de Herth. Foram utilizados Testes de Comparação de Média, Correlação de Pearson e regressão logística binária. Resultados: Preditores de desesperança foram diagnósticos psiquiátricos, tratamento em saúde mental, ausência de crença religiosa e insatisfação com o apoio social recebido. As chances de pensamento suicidas foram maiores entre pessoas com diagnósticos psiquiátricos, insatisfeitas com o apoio social recebido, compreensíveis em relação ao direito ao suicídio e na presença de desesperança. Os preditores de sentimentos negativos relacionados ao comportamento suicida foram a menor competência profissional autopercebida e a não participação em eventos científicos 
relacionados à temática. Estudantes mais velhos e aqueles com menos pensamentos suicidas tiveram maiores chances de apresentar atitudes condenatórias. Preditores de menor competência profissional autopercebida foram sentimentos negativos relacionados ao comportamento suicida, insatisfação com apoio social recebido, menor exposição educacional (leituras e participação em eventos sobre a temática) e não ter conhecidos/amigos em risco de suicídio. Conclusão: É fundamental desenvolver e avaliar estratégias educativas e de apoio para graduandos que considerem os fatores investigados neste estudo, no intuito de promover esperança e subsídios para a prevenção do suicídio.

Palavras-chave: Esperança; Conhecimentos, atitudes e prática em saúde; Enfermagem.

\section{Resumen}

Objetivo: Investigar, entre estudiantes de enfermería, los predictores de esperanza, los pensamientos suicidas y las actitudes hacia la conducta suicida. Método: estudio transversal, con enfoque cuantitativo, desarrollado en 2018 con 337 estudiantes de pregrado de una Universidad pública brasileña. Se aplicó el cuestionario sociodemográfico, clínico y psicosocial; el Cuestionario de Actitudes hacia la Conducta Suicida y la Escala de Esperanza de Herth. Se utilizaron pruebas de comparación de medias, correlación de Pearson y regresión logística binaria. Resultados: Los predictores de desesperanza fueron los diagnósticos psiquiátricos, el tratamiento de salud mental, la falta de creencias religiosas y la insatisfacción con el apoyo social recibido. Las probabilidades de pensamientos suicidas fueron mayores entre las personas con diagnósticos psiquiátricos, insatisfechas con el apoyo social recibido, comprensible en relación al derecho al suicidio y en presencia de desesperanza. Los predictores de sentimientos negativos relacionados con la conducta suicida fueron una menor competencia profesional autopercibida y la no participación en eventos científicos relacionados con el tema. Los estudiantes mayores y los que tenían menos pensamientos suicidas tenían más probabilidades de tener actitudes de condena. Los predictores de menor competencia profesional autopercibida fueron sentimientos negativos relacionados con la conducta suicida, insatisfacción con el apoyo social recibido, menor exposición educativa (lectura y participación en eventos sobre el tema) y no tener conocidos/amigos en riesgo de suicidio. Conclusión: Es fundamental desarrollar y evaluar estrategias de formación y apoyo a los estudiantes de pregrado que consideren los factores investigados en este estudio, con el fin de promover la esperanza y el apoyo para la prevención del suicidio.

Palabras clave: Esperanza; Conocimientos, actitudes y práctica en salud; Enfermería.

\section{Introduction}

Suicide is a considerable public health problem. In 2016, nearly 800,000 people die by suicide, it is worth mentioning that men are more likely to use lethal methods and the suicide rates in this population increase with age. In addition, suicide rates were two times higher in men when compared to women, and its incidence reaches a peak among people aged 15 to 29 years (WHO, 2019).

Understanding suicidal ideations and its risk factors, as well as, monitoring them are important actions for suicide prevention (Hallensleben et al., 2019). The investigation of suicidal thoughts among nursing undergraduates is relevant because this population is exposed to risks related to the strong and contradictory feelings experienced during university studies (Leal \& Santos, 2016) and have a high prevalence of psychological stress (Ryan et al., 2010). In the university context, boys appear to be more likely to engage in suicidal ideation and behavior while girls have more social support mainly from parents and professors (Madjar et al., 2018).

Hopelessness is one of the factors associated with suicidal behavior (Beck et al., 1974). Hopelessness is defined as the presence of negative feelings about the future (Beck et al., 1974) and helplessness to overcome these perspectives (Klonsky et al., 2012). Hope is characterized as a positive motivation towards a successful future (Snyder et al., 1991), a motivation for individual actions (Sartore \& Grossi, 2008), an adaptive response, prediction of a better future, what sustains people in times of helplessness (Tong, 2015). Lower levels of hope may be associated with suicidal ideation (Beck et al., 1974; Chang, 2017) and worse academic performance (Feldman \& Kubota, 2015). In addition, for future nursing professionals, hope can be important to establish a therapeutic relationship with patients (Goodwin et al., 2016; Sartore \& Grossi, 2008).

Attitudes related to suicidal behavior are important indications of the professional's preparation to act in the suicide prevention, as they signal professional competence, as well as the distance and anger behaviors and feelings of helplessness (Botega et al., 2005). Studies have shown that attitudes of health professionals and undergraduates towards suicidal behavior 
are associated with their training and the exposition to different types of educational strategies (Moraes et al., 2016; Saunders et al., 2012; Vedana \& Zanetti, 2019).

A study conducted with Brazilian nursing students revealed that undergraduates consider suicidal behavior as complex and challenging (Vedana et al., 2017c). In addition, students reported that they want to avoid situations related to this topic as a form of self-protection, as well as pointed divergences between their own beliefs and the behaviors required in health care (Vedana et al., 2017b). Furthermore, nursing students also reported low and irregular educational exposure on this subject during their university course (Moraes et al., 2016; Vedana et al., 2017a). Understanding student's attitudes towards suicidal behavior can support strategies for the training of these professionals, and may contribute to qualify the academic education (Vedana \& Zanetti, 2019), and provide student support interventions and suicide prevent actions in academic context by identifying warning signs among peers and encouraging the search for help (Aldrich, 2018).

Considering the importance of investigating factors that may contribute to support and the qualification of professional training for the suicide prevention, the objective of this study was to investigate, among nursing undergraduate students, the predictors of hope, lifetime suicidal thoughts and attitudes related to suicidal behavior.

\section{Methodology}

This is an analytical cross-sectional study, with quantitative approach (Polit \& Beck, 2019) conducted in a public university located in a city in the interior of the state of São Paulo. At the time of data collection, the institution offered the courses of Bachelor in Nursing (8 semesters) and Bachelor's degree in nursing with a teaching diploma (10 semesters).

All students enrolled in the Nursing undergraduate courses of the university were recruited for the study. Exclusion criteria were: students under 18 years old or those who were absent at the time of data collection. The population eligible for the study was 544 nursing undergraduate students; there were 2 refusals and 205 absences. The sample were composed by 337 students.

We performed the data collection from August to December 2018, after receiving the authorization from the educational institution and the approval of the Research Ethics Committee. Students were informed about the study procedures and those who voluntarily agreed to participate, signed an informed consent form. Data were collected by the researchers during the beginning or end of class, periods previously accorded with the university professors. The researchers who collected data were not University employees.

The participants completed three data collection instruments: (1) a sociodemographic, clinical and psychosocial questionnaire; (2) the Suicide Behavior Attitude Questionnaire (SBAQ); and (3) Herth Hope Scale (HHS). The sociodemographic, clinical and psychosocial data questionnaire contains questions regarding the course period; the participation in other educational courses and lectures or participation in scientific events that address mental health or suicide prevention issues; the participation in discipline related to mental health or psychiatry; the use of psychotropic medication; the diagnosis of mental disorder; the experience of having contact with a family member and/or close friend at suicide risk; the spirituality or religious belief, and the satisfaction with social support.

The SBAQ is a Brazilian instrument that measures health professionals' attitudes towards suicidal behavior (Botega et al., 2005). The questionnaire has 21 statements and each one is followed by a ten-centimeter (10-point) visual analog scale ranging from "strongly disagree" to "strongly agree". The items gathered evaluate three factors (the scores can range from 0 to 30 points): 1- Feelings towards the patient (higher scores indicate distance, anger and a feeling of helplessness); 2- Perception of professional capacity (higher scores indicate higher self-perceived competence); and 3- Right to suicide (higher score may represent a more understanding and less "moralistic / judicious" attitudes). The instrument does not have cutoff points and can 
be analyzed either by the three factors or by isolated analysis of the 21 items (Botega et al., 2005). The authors who developed the SBAQ authorized the use of this questionnaire in this study.

The HHS is a North American instrument adapted to the Brazilian Portuguese language by Sartore and Grossi (2008). This Likert-type scale contains 12 items, rated on a 4-point scale, ranging from 1 to 4 points, with 1 indicating "strongly disagree" and 4 "strongly agree". The total score ranges from 12 to 48, and this scale has no defined cutoff point. Thus, the higher the score reached, the higher the level of hope. Items 3 (three) and 6 (six) have inverted scores (Sartore \& Grossi, 2008). Authorization to use the scale in this study was obtained.

We coded the data and double entered it in a structured database in spreadsheet format, in Excel program. Possible coding or typing errors were corrected. Then, the data were transported and analyzed using the IBM SPSS Statistics for Windows, version 20 (IBM Corp., Armonk, N.Y., USA).

We analyzed the categorical variables using simple frequency and the numerical variables by measures of central tendency (mean and median), dispersion (standard deviation - SD) and interval. To investigate possible associations between variables, we employed mean comparison tests and correlation tests.

Then, we created multiple logistic regression models in order to identify the predictors for the five outcomes: 1. Hope (dichotomized in yes/no: values equal to or greater than the median were classified as highest level of hope); 2. Lifetime suicidal thoughts (dichotomized in yes/no: values equal to or less than the median were classified as less suicidal thoughts); 3. Negative feelings about suicidal behavior (dichotomized in yes/no: values equal to or lower than the median were classified as less negative feelings); 4. Self-perceived competence (dichotomized in yes/no: values equal to or higher than the median were classified as higher self-perceived competence); and 5. Right to suicide (dichotomized in yes/no: values equal to or higher than the median were classified as a higher right to suicide). The independent variables were selected for the logistic regression model using Pearson's Chi-square, Fisher's Exact, Mann-Whitney U tests and according to the researchers' knowledge on the topic. For each model, the Variance Inflation Factor (VIF) was also calculated to verify the presence of multicollinearity between the independent variables of the model. VIF values higher than 10 indicate the presence of multicollinearity (Montgomery et al., 2012). Finally, the odds ratio values were calculated (OR) with the respective $95 \%$ of confidence intervals $(\mathrm{CI})$. We adopted the level of significance of $5 \%($ alpha $=0,05)$ for all analyzes.

\section{Results}

In total, 337 students participated in this study, participants had ages ranging from 18.1 to 38.4 years, with an average of 21.6 years $(S D=2.3)$. Most were female $(86.7 \%)$, had religious belief $(84.9 \%)$, were satisfied with the support they received from other people (68.3\%), denied psychiatric diagnosis (74.3\%), were not using psychotropic drugs (86.1\%) and were not in treatment for mental health problems $(82.0 \%)$. The majority of the sample reported having had contact with a family member or close friend at suicide risk (64.2\%), but denied having known people who died by suicide (77.5\%).

Most of the students were matriculated in the undergraduate course of Bachelor in Nursing (56.2\%), were enrolled in the final years of the course (52.3\%) reported having attended mental health discipline (74.3\%), participated in scientific events involving the topic of suicide prevention (66.3\%) and read educational materials regarding this subject (55.0\%).

In this study, we evaluated the levels of hope using the HHS, which the total score may vary from 12.0 to 48.0 points. Among the study participants, the score ranged from 14.0 to 47.0 , the average was $34.83(S D=6.0)$ and the median was 35.0 points. Regarding the SBAQ factors, a higher score was found on factor 3, regarding the right of suicide (indicating a more empathetic and less condemnatory attitudes) and a lower score on factor 1, which focus on the feelings about suicidal behavior (indicating less negative feelings) towards suicidal behavior. 
In the association tests, hope was related to age, self-perceived professional competence, the right to suicide, suicidal thoughts, religious belief, satisfaction with social support, mental disorder diagnosis, psychiatric treatment and previous contact with someone close who was at risk of suicide (data not shown).

In the multivariate analysis, the predictors of less hope were: being diagnosed with a mental disorder $(\mathrm{OR}=2.377$; $\mathrm{p}=0.006)$ receiving psychiatric treatment $(\mathrm{OR}=2.328 ; \mathrm{p}=0.019)$, and, especially, the absence of religious beliefs $(\mathrm{OR}=4.937$; $\mathrm{p}=<0.001)$ and dissatisfaction with the social support received $(\mathrm{OR}=6.703 ; \mathrm{p}=<0.001)$ (Table 1$)$.

Table 1. Predictors of less hope, assessed by the HHS, among nursing students ( $n=337)$.

\begin{tabular}{|c|c|c|c|c|}
\hline \multirow[t]{2}{*}{ Variables } & \multicolumn{4}{|c|}{ Hope } \\
\hline & \multicolumn{2}{|c|}{ Crude } & \multicolumn{2}{|l|}{ Adjusted } \\
\hline & OR $(95 \% \mathrm{CI})$ & p-value & OR $(95 \% \mathrm{CI})$ & p-value \\
\hline $\begin{array}{c}\text { Have psychiatric } \\
\text { diagnosis }\end{array}$ & $3.038(1.807 ; 5.110)$ & $<0.001$ & $2.377(1.281 ; 4.413)$ & 0.006 \\
\hline $\begin{array}{l}\text { Treatment in mental } \\
\text { health }\end{array}$ & $3.035(1.667 ; 5.526)$ & $<0.001$ & $2.328(1.147 ; 4.725)$ & 0.019 \\
\hline $\begin{array}{l}\text { Religious belief } \\
\quad \text { (without) }\end{array}$ & $4.713(2.324 ; 9.556)$ & $<0.001$ & $4.937(2.302 ; 10.593)$ & $<0.001$ \\
\hline Psychotropic drugs use & $3.194(1.619 ; 6.303)$ & 0.001 & - & - \\
\hline $\begin{array}{l}\text { Dissatisfaction with } \\
\text { social support }\end{array}$ & $6.683(3.913 ; 11.412)$ & $<0.001$ & $6.703(3.801 ; 11.819)$ & $<0.001$ \\
\hline $\begin{array}{l}\text { Less right to suicide } \\
\text { (higher judgmental } \\
\text { attitudes) }\end{array}$ & $0.464(0.301 ; 0.717)$ & 0.001 & - & - \\
\hline $\begin{array}{l}\text { Less self-perceived } \\
\text { professional competence }\end{array}$ & $1.460(0.951 ; 2.241)$ & 0.083 & - & - \\
\hline $\begin{array}{l}\text { Have known people who } \\
\text { were at suicide risk }\end{array}$ & $1.519(0.970 ; 2.379)$ & 0.068 & - & - \\
\hline Age & $0.950(0.862 ; 1.046)$ & 0.297 & - & - \\
\hline
\end{tabular}

Note . Test $=$ Binary logistic regression model $O R=$ Odds ratio $C I=$ Confidence interval. Source: Authors.

Experiencing fewer suicidal thoughts during lifetime $(\mathrm{OR}=2.506 ; \mathrm{p}=<0.001)$ and older age $(\mathrm{OR}=1.173 ; \mathrm{p}=0.005)$ were predictors of less understanding about the right to suicide (table 2). In the mean comparison tests, the right to suicide was also associated with religious belief and attend suicide prevention events (data not shown). 
Table 2. Predictors of the less right to suicide, assessed by the SBAQ, among nursing students ( $\mathrm{n}=337)$.

\begin{tabular}{|c|c|c|c|c|}
\hline \multirow[t]{2}{*}{ Variables } & \multicolumn{3}{|c|}{ Right to suicide } & \multirow[b]{3}{*}{ p-value } \\
\hline & Crude & \multicolumn{2}{|c|}{ Adjusted } & \\
\hline & OR $(95 \% \mathrm{CI})$ & p-value & OR $(95 \% \mathrm{CI})$ & \\
\hline $\begin{array}{l}\text { Attend scientific events } \\
\text { (do not) }\end{array}$ & $0.581(0.367 ; 0.922)$ & 0.021 & - & - \\
\hline Have less suicidal thoughts & $2.287(1.475 ; 3.545)$ & $<0.001$ & $2.506(1.590 ; 3.949)$ & $<0.001$ \\
\hline Age & $1.159(1.040 ; 1.292)$ & 0.008 & $1.173(1.049 ; 1.313)$ & 0.005 \\
\hline More hope & $2.235(1.442 ; 3.464)$ & $<0.00$ & - & - \\
\hline
\end{tabular}

Note . Test $=$ Binary logistic regression model; $O R=$ Odds ratio $C I=$ Confidence interval. Source: Authors.

In the association tests, the negative feelings related to suicidal behavior were associated with self-perceived professional competence, attending scientific events and reading suicide prevention materials (data not shown). In the logistic regression model, the predictors of more negative feelings were the less self-perceived professional competence $(\mathrm{OR}=2.705$; $\mathrm{p}=<0.001)$ and not attending scientific events related to suicide prevention (OR=1.647; $\mathrm{p}=0.041)$ (Table 3).

Table 3. Predictors of negative feelings related to suicidal behavior assessed by the SBAQ ( $n=337)$.

\begin{tabular}{|c|c|c|c|c|}
\hline \multirow[t]{2}{*}{ Variables } & \multicolumn{3}{|c|}{ Negative feelings } & \\
\hline & \multicolumn{2}{|l|}{ Crude } & \multicolumn{2}{|l|}{ Adjusted } \\
\hline & OR $(95 \% \mathrm{CI})$ & p-value & OR $(95 \% \mathrm{CI})$ & p-value \\
\hline Readings (not) & $1.409(0.916 ; 2.167)$ & 0.119 & - & - \\
\hline $\begin{array}{l}\text { Attend scientific events } \\
\qquad \text { (do not) }\end{array}$ & $1.992(1.258 ; 3.153)$ & 0.003 & $1.647(1.021 ; 2.659)$ & 0.041 \\
\hline $\begin{array}{l}\text { Less self-perceived } \\
\text { professional competence }\end{array}$ & $2.949(1.894 ; 4.592)$ & $<0.001$ & $2.705(1.723 ; 4.247)$ & $<0.001$ \\
\hline
\end{tabular}

Note . Test $=$ Binary logistic regression model $O R=$ Odds ratio $C I=$ Confidence interval. Source: Authors.

The predictors of less self-perceived professional competence were the non participation in scientific events $(\mathrm{OR}=1.941 ; \mathrm{p}=0.010)$, the absence of reading suicide prevention materials $(\mathrm{OR}=1.994 ; \mathrm{p}=0.005)$, not having had previous contact with a family member or close friend at suicide risk $(\mathrm{OR}=1.707 ; \mathrm{p}=0.036)$, have negative feelings related to suicidal behavior $(\mathrm{OR}=2.701 ; \mathrm{p}=<0.001)$ and the dissatisfaction with the available social support $(\mathrm{OR}=2.378 ; \mathrm{p}=0.001)(\mathrm{data}$ not shown). In mean comparison tests (data not shown), the course period was also associated with self-perceived professional competence (which was not maintained in the regression model) (Table 4). 
Table 4. Predictors of less self-perceived professional competence, assessed by the SBAQ, among nursing students ( $\mathrm{n}=337$ ).

\begin{tabular}{|c|c|c|c|c|}
\hline \multirow[t]{3}{*}{ Variables } & \multicolumn{3}{|c|}{ Self-perceived professional competence } & \\
\hline & \multicolumn{2}{|l|}{ Crude } & \multicolumn{2}{|l|}{ Adjusted } \\
\hline & OR $(95 \% \mathrm{CI})$ & p-value & OR $(95 \% \mathrm{CI})$ & p-value \\
\hline Readings (not) & $2.208(1.426 ; 3.418)$ & $<0.001$ & $1.994(1.233 ; 3.224)$ & 0.005 \\
\hline $\begin{array}{l}\text { Attend scientific events } \\
\qquad \text { (do not) }\end{array}$ & $2.508(1.574 ; 3.996)$ & $<0.001$ & $1.941(1.174 ; 3.210)$ & 0.010 \\
\hline $\begin{array}{c}\text { First and second semester of } \\
\text { graduation }\end{array}$ & $2.046(1.326 ; 3.157)$ & 0.001 & - & - \\
\hline $\begin{array}{l}\text { Do not known people who } \\
\text { were at suicide risk }\end{array}$ & $1.730(1.104 ; 2.712)$ & 0.017 & $1.707(1.035 ; 2.814)$ & 0.036 \\
\hline $\begin{array}{l}\text { Dissatisfaction with social } \\
\text { support }\end{array}$ & $2.041(1.276 ; 3.263)$ & 0.003 & $2.378(1.410 ; 4.009)$ & 0.001 \\
\hline More negative feelings & $2.949(1.894 ; 4.592)$ & $<0.001$ & $2.701(1.689 ; 4.321)$ & $<0.001$ \\
\hline
\end{tabular}

Note . Test $=$ Binary logistic regression model; $O R=$ Odds ratio $C I=$ Confidence interval. Source: Authors.

In the association tests, lifetime suicidal thoughts (assessed by the SBAQ) were associated with several variables: reading material about suicide prevention, diagnosis of mental disorder, psychiatric treatment, religious belief, satisfaction with social support, right to suicide, close contact with people at suicide risk, and hope (data not shown).

In the logistic regression model, the predictors of lifetime suicidal thoughts were the diagnosis of mental disorder $(\mathrm{OR}=1.879 ; \mathrm{p}=0.037)$, the dissatisfaction with the received social support $(\mathrm{OR}=2.444 ; \mathrm{p}=0.002)$, the more understanding of the right to suicide $(\mathrm{OR}=1.845 ; \mathrm{p}=0.018)$ and the lower level of hope $(\mathrm{OR}=5.433 ; \mathrm{p}=<0.001)$, highlighting the hopelessness as a stronger predictor of suicidal thoughts (Table 5). 
Table 5. Predictors of more suicidal thoughts during lifetime, assessed by the SBAQ, among nursing students ( $\mathrm{n}=337$ ).

\begin{tabular}{|c|c|c|c|c|c|}
\hline \multirow[t]{2}{*}{ Variables } & \multicolumn{5}{|c|}{ Suicidal thoughts } \\
\hline & \multicolumn{2}{|c|}{ Crude } & \multicolumn{3}{|l|}{ Adjusted } \\
\hline & OR $(95 \% \mathrm{CI})$ & p-value & \multicolumn{2}{|c|}{ OR $(95 \% \mathrm{CI})$} & p-value \\
\hline Readings (yes) & $1.277(0.831 ; 1.962)$ & 0.265 & & - & - \\
\hline $\begin{array}{l}\text { Known people who were } \\
\text { at suicide risk }\end{array}$ & $1.847(1.175 ; 2.901)$ & 0.008 & & - & - \\
\hline $\begin{array}{l}\text { Have psychiatric } \\
\text { diagnosis }\end{array}$ & $2.743(1.638 ; 4.593)$ & $<0.001$ & 1.879 & $(1.039 ; 3.400)$ & $\mathbf{0 . 0 3 7}$ \\
\hline $\begin{array}{l}\text { Treatment in mental } \\
\text { health (not) }\end{array}$ & $0.574(0.326 ; 1.010)$ & 0.054 & & - & - \\
\hline $\begin{array}{l}\text { Psychotropic drugs use } \\
\text { (not) }\end{array}$ & $0.687(0.369 ; 1.280)$ & 0.237 & & - & - \\
\hline $\begin{array}{l}\text { Religious belief } \\
\quad \text { (without) }\end{array}$ & $2.316(1.237 ; 4.334)$ & 0.009 & & - & - \\
\hline $\begin{array}{l}\text { Dissatisfaction with } \\
\text { social support }\end{array}$ & $4.527(2.727 ; 7.515)$ & $<0.001$ & 2.444 & $(1.372 ; 4.353)$ & 0.002 \\
\hline $\begin{array}{l}\text { More right to suicide } \\
\text { (less judgmental } \\
\text { attitudes) }\end{array}$ & $2.262(1.464 ; 3.496)$ & $<0.001$ & 1.845 & $(1.111 ; 3.063)$ & 0.018 \\
\hline Less hope & $8.586(5.262 ; 14.011)$ & $<0.001$ & 5.433 & $(3.202 ; 9.220)$ & $<0.001$ \\
\hline
\end{tabular}

Note . Test $=$ Binary logistic regression model $O R=$ Odds ratio $C I=$ Confidence interval. Source: Authors.

\section{Discussion}

Most participants had religious belief and this characteristic was associated with less suicidal thoughts, more condemnatory attitudes towards suicidal behavior and was a predictor of hope. The literature reveals that the relationship between religiosity and suicide may vary depending on several individual, cultural and social factors (Wu et al., 2015). Studies show that religiosity can be a protective factor against suicide attempts (Rasic et al., 2011) and suicide death (Wu et al., 2015), as well as predisposing to condemning attitudes (Botega et al., 2005), but this is not a consensus (Neville \& Roan, 2013). Our study showed that religious belief was associated with suicidal thoughts, but not a predictor of those thoughts. It is possible that other mediating variables may explain the mechanisms of this association, such as hope (Li et al., 2020) and satisfaction with social support, which can be promoted by religiosity (Koenig et al., 2020) or even attitudes towards suicide behavior (more welcoming or condemnatory) propagated in each context. It is noteworthy that religious belief was one of the strongest predictors of hope in the present study.

Lower levels of hope were predictors of suicidal thoughts, because people with less hope had approximately five times the chance of having lifetime suicidal thoughts when compared to people with more hope. In literature, hopelessness is as a predictor of suicide attempts (Klonsky et al., 2012) and have positive correlations with suicidal ideation (Hallensleben et al., 2019) and suicide risk ( $\mathrm{Li}$ et al., 2020). It is important to recognize and intervene on risk factors for hopelessness, which in this study were: having psychiatric diagnoses, being in mental health treatment, the absence of religious belief and the 
dissatisfaction with social support. Our study also showed that hope was associated (although not as a predictor) with selfperceived professional competence and condemnatory attitudes.

Most of the undergraduates in this study were satisfied with the social support received. Students dissatisfied with the received social support are approximately seven times more likely to have less hope and had twice the chance of having suicidal thoughts, when compared to people satisfied with support. Other studies have also shown a positive relationship between hope and social support (Tan et al., 2018). Social support is also negatively related to depressive symptoms (Geffken et al., 2006). Among students, less support from professors, colleagues (social group) and parents are associated with suicidal ideation in the academic context (Leal \& Santos, 2016; Madjar et al., 2018).

A minority of students reported having psychiatric diagnoses, using psychiatric drugs or being under psychiatric treatment, and these variables were associated with lower hope and more suicidal thoughts. Among these variables, only the psychiatric diagnosis was a predictor of suicidal thoughts. The literature also demonstrated a strong association between mental illness and suicide risk (Gomes et al., 2019) and suicide attempts (Sun \& Zhang, 2018). Some psychiatric diagnoses, such as obsessive compulsive disorder (OCD) (Geffken et al., 2006) and depression (Li et al., 2018) have already been identified as associated factors with less hope, while high levels of hope are associated with a reduction of anxiety and depressive symptoms (Kelberer et al., 2018).

The suicide exposure is a target of concern in the literature because it is associated with suicidal thoughts and suicide attempts (Swanson \& Colman, 2013; Vedana \& Zanetti, 2019). However, students exposed to suicide, may have a greater belief that it is possible to intervene to prevent suicide (Aldrich, 2018). In our study, this experience was not a predictor of hopelessness and suicidal thoughts (although it was associated with these outcomes). The lack of experience in dealing with close people at suicide risk was uncommon in our sample, and it was a predictor of less self-perceived professional competence. These findings reveal the importance of including, in the academic context, discussion spaces so that students can have greater training and development of emotional skills to cope with situations that may be part of their personal lives.

Most of the students were in the final years of the course and reported having attended mental health discipline, attending a scientific event and reading suicide prevention materials, which did not occur in other studies (Vedana \& Zanetti, 2019). The association tests showed that students at the end of the course had more self-perceived professional competence.

The non-participation in scientific events was an associated factor with less condemnatory attitudes, predictor of less self-perceived competence and more negative feelings regarding suicidal behavior. Only one study carried out with Portuguese nursing students identified the association between participating in scientific events and more condemnatory attitudes towards suicidal behavior (Vedana et al., 2020), because, in general, professional training (using different strategies and resources) is associated with more favorable attitudes related to the person with suicidal behavior (Botega et al., 2005; Bott et al., 2015; Kishi et al., 2011; Moraes et al., 2016; Norheim et al., 2016; Ramberg et al., 2016).

In our study, reading suicide prevention materials was associated with less negative feelings and more suicidal thoughts. Not reading about suicide prevention was a predictor of less self-perceived professional competence. Considering these associations, it is important to know the quality of the materials accessed by students, and the (personal or academic) motivations for reading (Vedana et al., 2020), as well as their potential to promote mental health and suicide prevention literacy.

As in other studies, negative feelings about suicide increased the chance of less self-perceived professional competence (Vedana et al., 2017b; Vedana \& Zanetti, 2019). It is possible that the negative feelings (distance, anger and a feeling of helplessness) are more intense when the student presents this self-perception of unpreparedness (Vedana \& Zanetti, 2019; Vedana et al., 2020) or shows less interest in deepening their knowledge of suicide (Vedana et al., 2017c). 
Regarding the perception of the right to suicide, less suicidal thoughts and older age were predictors of more condemnatory attitudes (less empathy and higher judgment). The association between younger nursing professionals and more positive attitudes were also found in the analysis of Neville and Roan (2013). People with an experience related to suicide risk may be more empathic, have less condemnatory attitudes (Moraes et al., 2016; Vedana \& Zanetti, 2019) and have more positive attitudes towards suicidal behavior (Cwik et al., 2017).

The present study has limitations, such as the cross-sectional design, investigation of lifetime suicidal thoughts (which does not allow the detailed assessment of suicide risk) and the convenience sample, that was used in order to include in the study the largest number of participants available at the data collection period. Despite the limitations, this study found important predictors of hopelessness, suicidal thoughts and attitudes related to suicidal behavior among nursing undergraduates, a public with vulnerabilities and, at the same time, at an important moment of training to assist people at suicide risk.

\section{Conclusion}

This study enabled a greater understanding of the predictive factors of hope, suicidal thoughts during the lifetime and attitudes related to suicidal behavior. The predictors of less hope were psychiatric diagnoses, mental health treatment, and especially, not having religious beliefs and dissatisfaction with the received social support. The chances of suicidal thoughts were higher among people with psychiatric disorder, dissatisfaction with social support, more understanding of the right to suicide and lower levels of hope, highlighting the hopelessness as a stronger predictor of suicidal thoughts.

Regarding the attitudes related to suicidal behavior, less self-perceived professional competence and non-participation in scientific events were predictors of negative feelings. Students with less lifetime suicidal thoughts or older ones were more likely to have condemnatory attitudes. The predictors of less self-perceived professional competence included not reading materials about suicide prevention, non-participation in scientific events, not having a family member/friend at suicide risk, dissatisfaction with the received social support and negative feelings toward suicidal behavior.

The contributions listed in the present study can support the design of investigations and interventions related to the support and educational strategies to health students for suicide prevention. Future researches should investigate these variables in other contexts to compare the results and obtain a sample that is representative of the general population.

\section{Acknowledgments}

Miyeko Hayashida for the support in the statistical analysis.

\section{Funding Source}

University of Sao Paulo through the Unified Scholarship Program (PUB-USP).

\section{References}

Aldrich, R. S. (2018). A closer look: College students' exposure to suicide and intention to intervene. Mental Health and Prevention, 11, 1-7. https://doi.org/10.1016/j.mhp.2018.04.001

Beck, A. T., Weissman, A., Lester, D., \& Trexler, L. (1974). The measurement of pessimism: the hopelessness scale. Journal of Consulting and Clinical Psychology, 42(6), 861-865. https://doi.org/10.1037/h0037562

Botega, N. J., Reginato, D. G., Volk, S., Filinto, C., Rapeli, C. B., Lúcia, M., Mauro, F.,Cecconi, J.P., \& Stefanello, S. (2005). Nursing personnel attitudes towards suicide : the development of a measure scale, 27(4), 315-318. https://doi.org/10.1590/S151644462005000400011

Bott, N. C. L., de Araujo, L. M. C., Costa, E. E., \& Machado, J. S. A. (2015). Nursing students attitudes across the suicidal behavior. Investigacion y Educacion En Enfermeria, 33(2), 334-342. https://doi.org/10.1590/S0120-53072015000200016 
Chang, E. C. (2017). Hope and hopelessness as predictors of suicide ideation in Hungarian college students students. Death Studies, 41(7), 455-460. https://doi.org/10.1080/07481187.2017.1299255

Cwik, J. C., Till, B., Bieda, A., Blackwell, S. E., Walter, C., \& Teismann, T. (2017). Measuring attitudes towards suicide: Preliminary evaluation of an attitude towards suicide scale. Comprehensive Psychiatry, 72, 56-65. https://doi.org/10.1016/j.comppsych.2016.09.008

Feldman, D. B., \& Kubota, M. (2015). Hope, self-efficacy, optimism, and academic achievement: Distinguishing constructs and levels of specificity in predicting college grade-point average. Learning and Individual Differences, 37, 210-216. https://doi.org/10.1016/j.lindif.2014.11.022

Geffken, G. R., Storch, E. A., Duke, D. C., Monaco, L., Lewin, A. B., \& Goodman, W. K. (2006). Hope and coping in family members of patients with obsessive-compulsive disorder. Journal of Anxiety Disorders, 20(5), 614-629. https://doi.org/10.1016/j.janxdis.2005.07.001

Gomes, A. P., Soares, A. L. G., Kieling, C., Rohde, L. A., \& Gonçalves, H. (2019). Mental disorders and suicide risk in emerging adulthood: The 1993 Pelotas birth cohort. Revista de Saude Publica, 53, 1-11. https://doi.org/10.11606/S1518-8787.20190530012356

Goodwin, J., Behan, L., Kelly, P., McCarthy, K., \& Horgan, A. (2016). Help-seeking behaviors and mental well-being of first year undergraduate university students. Psychiatry Research, 246, 129-135. https://doi.org/10.1016/j.psychres.2016.09.015

Hallensleben, N., Glaesmer, H., Forkmann, T., Rath, D., Strauss, M., Kersting, A., \& Spangenberg, L. (2019). Predicting suicidal ideation by interpersonal variables, hopelessness and depression in real-time. An ecological momentary assessment study in psychiatric inpatients with depression. European Psychiatry, 56, 43-50. https://doi.org/10.1016/j.eurpsy.2018.11.003

IBM Corp. Released 2011. IBM SPSS Statistics for Windows, Version 20.0. Armonk, NY: IBM Corp.

Kelberer, L. J. A., Kraines, M. A., \& Wells, T. T. (2018). Optimism, hope, and attention for emotional stimuli. Personality and Individual Differences, 124, 84-90. https://doi.org/10.1016/j.paid.2017.12.003

Kishi, Y., Kurosawa, H., Morimura, H., Hatta, K., \& Thurber, S. (2011). Attitudes of Japanese nursing personnel toward patients who have attempted suicide. General Hospital Psychiatry, 33(4), 393-397. https://doi.org/10.1016/j.genhosppsych.2011.02.005

Klonsky, E. D., Kotov, R., Bakst, S., Rabinowitz, J., \& Bromet, E. J. (2012). Hopelessness as a predictor of attempted suicide among first admission patients with psychosis: A 10-year cohort study. Suicide Life Threat Behav, 42(1), 1-10. https://doi.org/10.1111/j.1943-278X.2011.00066.x

Koenig, H. G., Youssef, N. A., Smothers, Z., Oliver, J. P., Boucher, N. A., Ames, D., Volk, F., Teng, E.J., \& Haynes, K. (2020). Hope, Religiosity, and Mental Health in U.S. Veterans and Active Duty Military with PTSD Symptoms. Military Medicine, 185(1-2), 97-104. https://doi.org/10.1093/milmed/usz146

Leal, S. C., \& Santos, J. C. (2016). Suicidal behaviors, social support and reasons for living among nursing students. Nurse Education Today, 36, 434-438. https://doi.org/10.1016/j.nedt.2015.09.012

Li, W., Dorstyn, D. S., \& Jarmon, E. (2020). Identifying suicide risk among college students: A systematic review. Death Studies, 44(7), 450-458. https://doi.org/10.1080/07481187.2019.1578305

Li, Z., Wang, Y., Mao, X., \& Yin, X. (2018). Relationship between hope and depression in college students: A cross-lagged regression analysis. Personality and Mental Health, 12(2), 170-176. https://doi.org/10.1002/pmh

Madjar, N., Walsh, S. D., \& Harel-Fisch, Y. (2018). Suicidal ideation and behaviors within the school context: Perceived teacher, peer and parental support. Psychiatry Research, 269, 185-190. https://doi.org/10.1016/j.psychres.2018.08.045

Montgomery, D. C., Peck, E. A., \& Vining, G. G. (2012). Introduction to linear regression analysis. (Wiley series in probability and statistics, 5th. ed., pp.296296). Hoboken, New Jersey: John Wiley \& Sons, Inc.

Moraes, S. M., Magrini, D. F., Zanetti, A. C. G., Santos, M. A. dos, \& Vedana, K. G. G. (2016). Atitudes relacionadas ao suicídio entre graduandos de enfermagem e fatores associados. Acta Paulista de Enfermagem, 29(6), 643-649. https://doi.org/10.1590/1982-0194201600090

Neville, K., \& Roan, N. M. (2013). Suicide in Hospitalized Medical-Surgical Patients: Exploring Nurses' Attitudes. Journal of Psychosocial Nursing, 51(1), 35-43. https://doi.org/10.3928/02793695-20121204-01

Norheim, A. B., Grimholt, T. K., Loskutova, E., \& Ekeberg, O. (2016). Attitudes toward suicidal behaviour among professionals at mental health outpatient clinics in Stavropol, Russia and Oslo, Norway. BMC Psychiatry, 16(1), 1-12. https://doi.org/10.1186/s12888-016-0976-5

Polit, D.F., Beck, C.T. (2019). Fundamentos de pesquisa em enfermagem: avaliação de evidências para a prática de enfermagem. Artmed, 9th edition.

Ramberg, I. L., Di Lucca, M. A., \& Hadlaczky, G. (2016). The impact of knowledge of suicide prevention and work experience among clinical staff on attitudes towards working with suicidal patients and suicide prevention. International Journal of Environmental Research and Public Health, 13(2), 1-12. https://doi.org/10.3390/ijerph13020195

Rasic, D., Robinson, J. A., Bolton, J., Bienvenu, O. J., \& Sareen, J. (2011). Longitudinal relationships of religious worship attendance and spirituality with major depression, anxiety disorders, and suicidal ideation and attempts: Findings from the Baltimore epidemiologic catchment area study. Journal of Psychiatric Research, 45(6), 848-854. https://doi.org/10.1016/j.jpsychires.2010.11.014

Ryan, M. L., Shochet, I. M., \& Stallman, H. M. (2010). Universal online interventions might engage psychologically distressed university students who are unlikely to seek formal help. Advances in Mental Health, 9(1), 73-83. https://doi.org/10.5172/jamh.9.1.73

Sartore, A. C., \& Grossi, S. A. A. (2008). Escala de Esperança de Herth - Instrumento adaptado e validado para a língua portuguesa. Rev Esc Enferm USP, $42(2), 227-232$ 
Saunders, K. E. A., Hawton, K., Fortune, S., \& Farrell, S. (2012). Attitudes and knowledge of clinical staff regarding people who self-harm: A systematic review. Journal of Affective Disorders, 139, 205-216. https://doi.org/10.1016/j.jad.2011.08.024

Snyder, C. R., Irving, L. M., \& Anderson, J. R. (1991). Hope and health. In Handbook of social and clinical psychology: The health perspective 162, 285-305. Sun, L., \& Zhang, J. (2018). Suicide Acceptability and Suicide Attempt: A Case-Control Study with Medically Serious Suicide Attempters Aged 15 to 54 Years in Rural China. Journal of Nervous and Mental Disease, 206(9), 694-698. https://doi.org/10.1097/NMD.0000000000000863

Swanson, S. A., \& Colman, I. (2013). Association between exposure to suicide and suicidality outcomes in youth. CMAJ, 185(10), 870-877. https://doi.org/10.1503/cmaj.121377

Tan, C. S., Low, S. K., \& Viapude, G. N. (2018). Extraversion and happiness: The mediating role of social support and hope. PsyCh Journal, 7(3), 133-143. https://doi.org/10.1002/pchj.220

Tong, E. M. W. (2015). Hope and Hopelessness. International Encyclopedia of the Social \& Behavioral Sciences: Second Edition (Second Edi, Vol. 11). Elsevier. https://doi.org/10.1016/B978-0-08-097086-8.25013-7

Vedana, K. G. G., Magrini, D. F., Zanetti, A. C. G., Miasso, A. I., Borges, T. L., \& Santos, M. A. dos. (2017a). Attitudes toward suicidal behavior and associated factors among nursing professionals: a quantitative study. Journal of Psychiatric and Mental Health Nursing, 24(9-10), 651-659. https://doi.org/10.1111/jpm.12413

Vedana, K. G. G., Magrini, D. F., Miasso, A. I., Zanetti, A. C. G., Souza, J., \& Borges, T. L. (2017b). Emergency nursing experiences in assisting people with suicidal behavior: A Grounded Theory Study. Archives of Psychiatric Nursing, 31(4), 345-351. http://dx.doi.org/10.1016/j.apnu.2017.04.003

Vedana, K. G. G., Pereira, C. C. M., Santos, J. C., Ventura, C. A. A., Moraes, S. M., Miasso, A. I., Zannetti, A.C. G. \& Borges, T. L. (2017c). The meaning of suicidal behaviour from the perspective of senior nursing undergraduate students. International Journal of Mental Health Nursing 27 (3), 1149-1161. https://doi.org/10.1111/inm.12431

Vedana, K. G. G., \& Zanetti, A. C. G. (2019). Atitudes de estudantes de enfermagem relacionadas ao comportamento suicida. Revista Latino-Americana de Enfermagem, 27, Article 3116, 1-8. https://doi.org/10.1590/1518-8345.2842.3116

Vedana, K. G. G., Santos, J. C., Zanetti, A. C. G., Miasso, A. I., Ventura, C. A. A., Pillon, S. C., Souza, J., \& Silva, A. C. (2020). Attitudes of Portuguese nursing undergraduate students toward suicidal behaviour. British Journal of Mental Health Nursing, 9(1), 41-49. https://doi.org/10.12968/bjmh.2018.0031

World Health Organization. (2019). World Health Statistics data visualizations dashboard. Noncommunicable diseases and mental health. Data tables. <https://www.who.int/gho/publications/world_health_statistics/2019/EN_WHS_2019_Main.pdf?ua=1>.

Wu, A., Wang, J.-Y., \& Jia, C.-X. (2015). Religion and completed suicide: A meta-analysis. PLoS ONE, 1O(6), 1-14. https://doi.org/10.1371/journal.pone.0131715 